\title{
KOMUNIKOWANIE O ZDROWIU I MEDYCYNIE - RZECZYWISTOŚĆ A PRZEKAZY MEDIALNE
}

\author{
Olga Białek-Szwed \\ Katolicki Uniwersytet Lubelski Jana Pawła II \\ Wydział Nauk Społecznych, Instytut Dziennikarstwa i Komunikacji Społecznej \\ ORCID: https://orcid.org/0000-0001-5702-4458 \\ e-mail: o.bialek.szwed@wp.pl
}

\begin{abstract}
Streszczenie: Artykuł omawia problemy pojawiające się w komunikacji pomiędzy pracownikiem służby zdrowia (lekarzem, pielęgniarką/pielęgniarzem, ratownikiem medycznym, stomatologiem, rehabilitantem, farmaceutą) a pacjentem. Wskazuje na asymetrię owych relacji, pokazuje różnicę pomiędzy dwoma sposobami komunikacji - autorytarnym i partnerskim. Próbuje zdiagnozować i opisać przeszkody, które utrudniają relację pacjent-lekarz. Na pojedynczych przykładach starano się pokazać, w jaki sposób współczesne media, przede wszystkim prasa, podejmują i realizują niniejszą tematykę.
\end{abstract}

Słowa kluczowe: komunikowanie o zdrowiu i medycynie, przekazy medialne na temat zdrowia i medycyny, komunikacja partnerska, komunikacja autorytarna, komunikacja werbalna i niewerbalna, bariery komunikacyjne

Kompetentna komunikacja w opiece medycznej to nie umiejętność, a sztuka przekazywania skomplikowanych czy niepomyślnych informacji; zdolność mówienia, ale i słuchania; umiejętność prowadzenia rozmowy z każdym i na każdym poziomie - z dziećmi i ich rodzicami, z pacjentami terminalnie chorymi, z osobami poddawanymi intensywnym i wyczerpującym terapiom, z którymi rozmowa jest utrudniona. By sprostać wymienionym wyzwaniom komunikacyjnym, uczelnie medyczne w Polsce wprowadziły do swojej siatki godzin przedmioty mające $\mathrm{w}$ tym celu edukować przyszłych pracowników służby zdrowia, nie tylko lekarzy, lecz także pielęgniarki i ratowników medycznych, a nawet przyszłych farmaceutów. Stało się tak zapewne dlatego, że zdaniem niektórych badaczy: „We współczesnej medycynie wciąż dominuje punkt widzenia, zgodnie z którym, tak choroba, jak i zdrowie są domeną medycyny" [Jarosz, Kawczyńska-Butrym, Włoszczak-Szubzda 2012: 212]. I oczywiście są domeną medyków. A w takiej perspektywie nie ma miejsca na podmiotowe, partnerskie traktowanie pacjenta. 
Istotę problemu podkreśla również fakt, że: „Jeszcze dziesięć, a nawet pięć lat temu zajęcia z komunikacji z pacjentami proponowano studentom uczelni medycznych tylko w ramach fakultetów. Na części uczelni były, na innych nie, trochę przypadkowo i chaotycznie" - na co zwracała uwagę Antonina Doroszewska, pełnomocnik rektora ds. utworzenia Centrum Edukacji Medycznej na Warszawskim Uniwersytecie Medycznym [Cieśla 2018: 31].

Celem niniejszego artykułu jest prezentacja relacji lekarz-pacjent na płaszczyźnie komunikacyjnej. Wyeksponowano trzy aspekty tego zagadnienia: sposób komunikowania się lekarzy z pacjentami w codziennej praktyce medycznej - jego błędy, niezręczności, ale i coraz większa świadomość potrzeby kompetencji w tym zakresie; dwa podstawowe typy komunikacji pojawiające się w relacji lekarzpacjent (spojrzenie językoznawcze) oraz to, co najważniejsze z punktu widzenia medioznawczego, czyli specyfika publicystyki dziennikarskiej na temat relacji lekarz-pacjent. Wszystkie występujące w artykule aspekty z założenia mają się uzupełniać, tak by ułatwić zrozumienie poruszanego problemu, spojrzeć na niego w sposób holistyczny.

\section{RELACJA LEKARZ-PACJENT}

Świadomość posiadania odpowiednich kompetencji komunikacyjnych zdaje się być w środowisku medycznym z roku na rok coraz większa. Potwierdzają to badania empiryczne i analiza modeli teoretycznych, przeprowadzane zarówno w środowisku medycznym, jak i w środowisku pacjentów oraz badania oceniające ich wzajemne relacje [Ostrowska 2001]. Jak zauważyła Antonina Ostrowska: „W ciągu ubiegłego wieku interakcje miedzy lekarzami i pacjentami ulegały systematycznym przemianom. Zmieniał się obraz chorób wymuszający nowe podejście lekarza do pacjenta, opieka lekarska stawała się bardziej powszechna i ogólnodostępna, a postęp medycyny wprowadzał coraz to nowe technologie [...] Wszystkie te zmiany nie pozostawały obojętne dla kształtu tych interakcji. Zmieniali się także lekarze i pacjenci. [...] Zmieniał się więc zakres symbolicznej władzy, jaką dysponowali partnerzy we wzajemnych relacjach" [Ostrowska 2011: 11]. Owa symboliczna władza, o której pisała Ostrowska, podyktowana jest asymetrią, która wynika z relacji lekarz-pacjent. To pacjent przychodzi do lekarza, to on potrzebuje wiedzy, umiejętności i pomocy pracownika opieki zdrowotnej. To pacjent musi obdarzyć zaufaniem najczęściej obcego człowieka. Dodatkowo ową asymetrię relacji uświadamia sytuacja pojedynczego pacjenta - najczęściej reprezentuje on sam siebie, czasami bliską mu osobę (męża, żonę, dziecko, rodziców itp.), podczas gdy za medykiem stoi cały system instytucji opieki zdrowotnej oraz prestiż wiedzy medycznej, często także tytułu naukowego. Jak pisał Jan Hartman: „Władza medyczna jest »piątą władzą « w państwie, lecz dla chorych jest władzą pierwszą. Z lekarzami nikt nie wygra - ni chorzy, ni premierzy - lepiej przeto z nimi nie wojować" [Hartman 2012: 36]. 
Badacze zajmujący się tematyką komunikowania lekarzy z pacjentami zwracają uwagę w swoich publikacjach na konieczność wypracowania jednolitego modelu, który byłby obowiązujący dla wszystkich reprezentantów zawodów medycznych mających bezpośredni kontakt z chorymi, niezależnie od posiadanej przez nich specjalizacji ${ }^{1}$. Niemniej jednak Izabela Stangierska i Wanda Horst-Sikorska szczególną rolę w komunikacji w medycynie przypisują umiejętnościom interpersonalnym lekarzy rodzinnych. Badaczki w lekarzach rodzinnych upatrują awangardę nowoczesnego sposobu komunikowania się lekarza z pacjentem [Stangierska, Horst-Sikorska 2007].

Wszelkie dostępne badania pokazują to, jak wiele jest jeszcze do zrobienia w tej materii. Jedne z nich, opublikowane w 2013 roku na portalu medexpress.pl., uświadamiają, że „64 procent pacjentów oczekuje od lekarzy w szpitalach przede wszystkim wyjaśnienia wszelkich kwestii związanych z planowanym zabiegiem bądź badaniem. A ponad połowa pytanych wśród najważniejszych wymagań umieszcza »wyrażanie się przez lekarzy w zrozumiały sposób «" [Boczek 2013]. Zdaniem Andrzeja Mądrala, wiceprezesa Ogólnopolskiego Stowarzyszenia Szpitali Prywatnych, ,na przykład chirurdzy uważają, że ich czas jest tak cenny, że nie mogą go poświęcać na rozmowę z pacjentem, by opisać mu procedury, jakie go czekają" [Boczek 2013]. Marcin Szulwiński, prezes Grupy Nowy Szpital podkreślił istotną rolę sposobu przekazania informacji przez lekarza pacjentowi w całym procesie leczenia. Jeśli lekarz komunikuje się z pacjentem w sposób dla niego zrozumiały, to nie tylko czuje się on bezpieczny i spokojny, ale też ma szansę aktywnie uczestniczyć w procesie leczenia, co z kolei może ułatwić niektóre, na przykład inwazyjne lub bolesne, niekomfortowe czy wstydliwe procedury medyczne. Według Szulwińskiego, by chory zechciał współpracować z personelem: „Lekarze i pielęgniarki muszą się tak zwracać do niego, aby ten poczuł się podmiotem i zaczął chcieć współpracować z nimi w procesie leczenia" [Boczek 2013].

W Polsce pierwszą siecią medyczną, która wprowadziła bieżący monitoring satysfakcji pacjentów z komunikacji lekarz-pacjent, był Lux Med. Od 2013 roku wszystkie placówki Grupy Lux Med i Medycyny Rodzinnej w ciągu 24 godzin po konsultacji medycznej wysyłają drogą mailową ankietę, która pozwala ocenić poziom zadowolenia albo frustracji z przebiegu wizyty lekarskiej. Przesyłana ankieta ocenia, czy pacjent otrzymał jasne i zrozumiałe informacje dotyczące stanu zdrowia; czy lekarz poświęcił mu tyle uwagi i zainteresowania, ile potrzebował; oraz czy lekarz rozwiał jego wszelkie wątpliwości. Pacjent może również wyrażać swoją opinię na temat zapewnionych warunków do prywatności i intymności podczas badania, jak również to, czy poleciłby danego specjalistę swojej rodzinie lub przyjaciołom [Lux Med 2013].

1 [Zob. Barański, Waszyński, Steciwko 2016; Barański, Steciwko 2013; Stangierska, Horst--Sikorska 2007: 58-68; Zembala 2015: 35-50; Jarosz, Kawczyńska-Butrym, Włoszczak-Szubzda 2012: 212-218]. 
Konstruktywny i partnerski dialog między lekarzem i pacjentem sprzyja nie tylko kondycji chorego, pomaga również przeprowadzić efektywny wywiad lekarzowi lub pielęgniarce. Badania prowadzone przez psychologów pokazały, że około 75 procent diagnozy lekarskiej stanowią informacje otrzymane w procesie komunikacji interpersonalnej pomiędzy lekarzem a pacjentem. Helena Motyka z Zakładu Pedagogiki Medycznej CM UJ w Krakowie zwróciła uwagę, że „pacjenci, którzy są zadowoleni z przebiegu swej komunikacji z personelem medycznym, wyżej oceniają całość otrzymanego leczenia, są bardziej zadowoleni z opieki i uzyskują lepsze efekty w terapii. Z drugiej strony, jak się okazuje, większość skarg pacjentów kierowanych do rzeczników praw pacjenta, mogących znaleźć także swój wyraz w walce o odszkodowanie, wynika ze złej komunikacji z lekarzem niż z błędów natury czysto medycznej" [Motyka 2013]. Zdaniem Motyki mniej więcej połowa pacjentów opuszcza gabinet lekarza, mając mgliste pojęcie, co i jak dalej powinni robić. Zdarzają się też pacjenci, którzy wcale nie stosują się do zaleceń lekarskich, nie dlatego że je bojkotują, ale ponieważ ich nie rozumieją, nie pamiętają. Brak zrozumienia zaleceń lekarskich najczęściej wynika również ze złej komunikacji.

Komunikacja między lekarzem a pacjentem to specyficzny i trudny, ale nieunikniony rodzaj relacji społecznych, w których niewłaściwe i niedelikatne postępowanie, brak zrozumienia mogą utrudnić, a nawet uniemożliwić kontakt. Jak w każdej interakcji, tak i w tej między lekarzem a pacjentem natrafia się na liczne przeszkody - werbalne i pozawerbalne - takie jak pozycja ciała, gesty, mimika, ruchy oczu, dystans fizyczny, dźwięki parajęzykowe, kontakt wzrokowy czy dotyk. Tak więc o jakości komunikacji i jej efektywności nie przesądza tylko użycie kodu zrozumiałego dla nadawcy i odbiorcy, ale też bariery komunikacyjne. Przyczynami trudności w porozumiewaniu się lekarza i pacjenta bywają nieporozumienia, niezrozumienie informacji przekazywanej przez nadawcę, także niespójność i chaotyczność przekazu, opatrzne postrzeganie intencji, niewyraźna artykulacja słów, zbyt szybkie tempo mówienia, jąkanie się, nieprawidłowy akcent i intonacja, używanie gwary, której nie zna druga strona.

Jak na każdej płaszczyźnie komunikacyjnej, tak i w relacji lekarz-pacjent dodatkowymi barierami komunikacyjnymi mogą się okazać: różnice kulturowe, różnice w interpretacji przekazu ze względu na narodowość ${ }^{2}$ oraz stereotypy, prowadzące czasami do nazbyt szybkiej kategoryzacji interlokutora i reakcji na jego przekaz słowny. Przeszkodą mogą się też okazać gesty, które często zastępują słowa, a są uwarunkowane kulturowo (np. potakiwanie głową w Bułgarii wygląda jak u nas przeczenie).

Liczne bariery pojawiające się w komunikacji lekarz-pacjent implikują nie tylko frustracje obu stron, ale też tworzą anegdoty i żarty obrazujące porozumienie słabej jakości lub jego brak. Dowcipy przede wszystkim trafiają do internetu

2 Rozróżniamy tzw. kultury kontaktowe reprezentowane przez Latynosów i Arabów i niekontaktowe, które preferują dalszy dystans między rozmówcami (Skandynawowie, Japończycy). 
i bawią jego użytkowników, ale też paradoksalnie mogą poprawić komunikację, na przykład rozładowując napięcie towarzyszące wizycie u lekarza czy planowanemu pobytowi w szpitalu. Już Zygmunt Freud doceniał leczniczą funkcję żartów, które wyrażają obawy i pragnienia chorego oraz pomagają w zachowaniu równowagi psychicznej. Pewnie dlatego amerykańscy lekarze rozśmieszanie pacjentów traktują jako jedną z form terapii w onkologii, na co zwrócił uwagę Andrzej Hołdys. Chorym na raka puszcza się więc komedie, występy kabaretów, opowiada dowcipy. Spontaniczny śmiech zdaniem Amerykanów wywiera korzystny wpływ na układ odpornościowy, zwiększa tolerancję na ból i poprawia nastrój [Hołdys 2003]. Aleksandra Woźnicka z Katedry Języków Specjalistycznych Uniwersytetu Warszawskiego podkreśliła zaś rolę „czarnego humoru” w medycynie. Dokonała nawet klasyfikacji różnych jego form. Badaczka wyróżniła formy, w których humor/żart/ironia determinują treść komunikatu, tj.: aforyzmy o lekarzach, przejęzyczenia, definicje terminów medycznych, mikrodialogi - kalambury i mikrodialogi - nieporozumienia [Woźnicka 2013].

Jeszcze inną barierą stającą się coraz większym problemem we współczesnym komunikowaniu o zdrowiu stanowią sami pacjenci - coraz bardziej roszczeniowi, nieusatysfakcjonowani wizytą hipochondrycy oraz agresywni, pijani, będący pod wpływem substancji psychoaktywnych, niezrównoważeni psychicznie. W niektórych sytuacjach trudno jest mówić o jakimkolwiek poprawnym układzie komunikacyjnym, ponieważ jest on nie tylko niemożliwy, ale i przede wszystkim niebezpieczny. Na ten fakt coraz częściej zwracają uwagę nie tylko badacze zajmujący się problematyką komunikowania w medycynie, ale też i same media, szkoda tylko że w tym drugim przypadku zbyt często chodzi przede wszystkim o sensację i rozrywkę.

\section{TYPY UKŁADÓW KOMUNIKACYJNYCH W RELACJI LEKARZ-PACJENT}

Interesujące, że ową asymetrię w relacji pacjent-lekarz sygnalizuje nie tylko sytuacja społeczna, ale też leksyka wykorzystywana podczas komunikacji, która ma miejsce $\mathrm{w}$ gabinetach lekarskich. Takim przykładem uświadamiającym niejednorodność sytuacji komunikacyjnych jest użycie dwóch terminów „komunikowanie” i „komunikowanie się", które laikowi mogą się zdawać synonimiczne. Obydwa terminy wydają się mieć podobny zakres semantyczny - utożsamia się je z procesem porozumiewania się jednostek lub grup, którego celem jest wymiana myśli, informacji, idei. Należy jednak wiedzieć, że Walery Pisarek w publikacji zatytułowanej Wstęp do nauki o komunikowaniu zwrócił uwagę na fakt - nie dla wszystkich dostrzegalny, acz istotny - istnienia granicy pomiędzy terminami „komunikowanie” a „komunikowanie się” [Pisarek 2008]. Zgodnie z ustaleniami Pisarka granica występująca między obydwoma leksemami jest stosunkowo płynna, ponieważ trudno jest „znaleźć przykład absolutnej wszechmocy komunikatora, który by skutecznie decydował zarówno o tym, co i kiedy będzie komunikowa- 
ne, jak i o tym, co i kiedy będzie odbierane, jak będzie rozumiane oraz co i jak będzie percypowane i zapamiętane. Tak samo trudno o przykład rzeczywistej równorzędności wszystkich komunikujących się partnerów". Mimo tych trudności różnica występująca między terminami ,komunikowanie” a „komunikowanie się" nie powinna być bagatelizowana, to w niej bowiem - jak stwierdził krakowski badacz - widoczna jest różnica pomiędzy dwoma sposobami komunikacji ${ }^{3}$ - autorytarnym i partnerskim ${ }^{4}$.

Układy komunikacyjne - zwane autorytarnym i partnerskim - są spotykane wszędzie, w każdym kontakcie komunikacyjnym, zarówno prywatnym, jak i publicznym, oraz w każdym systemie społecznym. Istotna jest tu budowa obu par wyrazów, która determinuje ich znaczenie. Jeśli bowiem „komunikujemy coś komuś", to jest to inny poziom porozumienia niż w przypadku „komunikowania się z kimś". Zupełnie odmiennie wygląda rozmowa z przedstawicielem środowiska medycznego, w której lekarz czy też pielęgniarka „komunikuje coś komuś”, a „komunikuje się z kimś". W drugim wypadku możemy mówić o układzie partnerskim, w pewien sposób nawet istnieniu jakiejś więzi porozumienia. W pierwszym mamy do czynienia z jednostronnym przekazywaniem treści, powiadamianiem odbiorcy, wyłącznie pouczaniem go. W sytuacji pierwszego typu pacjent może mieć wrażenie, że lekarz świadomie dzięki wyborowi sposobu komunikacji tworzy dystans, medyczne słownictwo bowiem, inaczej lekarska nowomowa, zwana też „medomową" lub z angielskiego „medspeakiem” czy „medicalspeakiem”, jest dla laika semantycznie niedostępna, hermetyczna, po prostu niezrozumiała. Przykładem „medomowy” jest używanie przez pracowników służby zdrowia eponimów, czyli określeń choroby nazwiskiem osoby, która ją odkryła i opisała jako pierwsza. $Z$ tych powszechnie znanych eponimów mamy zespół Downa, chorobę Alzheimera, zespół Hansa Aspergera, chorobę Leśniowskiego-Crohna czy zespół Turnera, ale obok tego funkcjonują setki eponimów, pacjentowi zupełnie nieznanych, którymi w jego obecności na co dzień posługują się lekarze. Żargon medyczny jest niezwykle dyskryminujący dla pacjenta, ponieważ już na

3 „Komunikowanie - w szerokim sensie to wszelkie (techniczne, biologiczne, psychiczne i społeczne) strukturalnie podobne do siebie procesy przekazywania informacji. W sensie węższym przez komunikowanie rozumie się tylko przenoszenie informacji (znaczeń) między istotami żywymi"' [zob. Pisarek 2008: 18]. Liczne definicje komunikowania, pojęcia, rodzaje, modele, środki i formy komunikowania itd. podaje również T. Goban-Klas [zob. Goban-Klas 1999].

4 W literaturze medycznej, w opisach relacji lekarz-pacjent pojawiają się jeszcze inne modele komunikacji (obok autorytarnego i partnerskiego), takie jak: model paternalistyczny - gdzie wyłącznie lekarz decyduje, jaki sposób leczenia jest najodpowiedniejszy i w związku z tym stara się nakłonić pacjenta do jego podjęcia; model informacyjny - lekarz jest ekspertem, którego zadaniem jest dostarczenie pacjentowi wszelkich informacji na temat jego choroby, ale to pacjent finalnie dokonuje wyboru metod leczenia; model interpretacyjny - lekarz przekazuje informacje o stanie zdrowia pacjenta, o ryzyku i korzyściach związanych z różnymi sposobami postępowania, pomaga interpretować dostarczane dane; model deliberacyjny - lekarz przyjmuje rolę przyjaciela, przewodnika, nauczyciela, który prowadzi dialog z pacjentem, wspólnie zastanawia się z nim nad pozytywnymi i negatywnymi aspektami różnych terapii [zob. Emanuel, Emanuel 1992: 2221-2226]. 
samym początku wyklucza go z czynnej komunikacji z lekarzem prowadzącym. Równocześnie lekarska nowomowa jest, zdaniem jednego z anglosaskich badaczy medspeaku [Christy 1979: 508], niejako pierwszym językiem lekarzy, podczas gdy język ojczysty dopiero drugim; jest też rodzajem psychologicznej samoobrony, „murem obronnym”, za którym kryją się lekarze przed coraz większymi wymaganiami pacjentów i ich bliskich.

\section{RELACJA LEKARZ-PACJENT W PUBLICYSTYCE MEDIALNEJ}

Układy komunikacyjne, zwane autorytarnym i partnerskim, nawet jeśli w większości przypadków nie są tak nazwane, bywają zasadniczym przedmiotem publicystyki medialnej oscylującej wokół problematyki medycznej, w tym głównie układów lekarz-pacjent. Jak wskazuje dokonana na potrzeby niniejszego artykułu kwerenda współczesnych mediów, przede wszystkim prasy, materiałów na ten temat jest wiele. Choć, na co warto zwrócić uwagę, w licznych przypadkach pokazują one oddzielnie perspektywę lekarza i jego pacjenta. Najczęściej perspektywy te nie są ze sobą kompatybilne, tzn. albo mamy artykuły na temat złego traktowania pacjenta i jego rodziny przez reprezentantów służby zdrowia, gdzie nie ma specjalnie miejsca na zaprezentowanie racji drugiej strony, albo jest to wyłącznie perspektywa medyków wskazująca na roszczeniowość pacjenta i jego bliskich, w których brakuje zrozumienia i docenienia odpowiedzialnej i niejednokrotnie wyczerpującej nie tylko fizycznie, ale i psychicznie pracy lekarzy i pielęgniarek, położnych, ratowników medycznych.

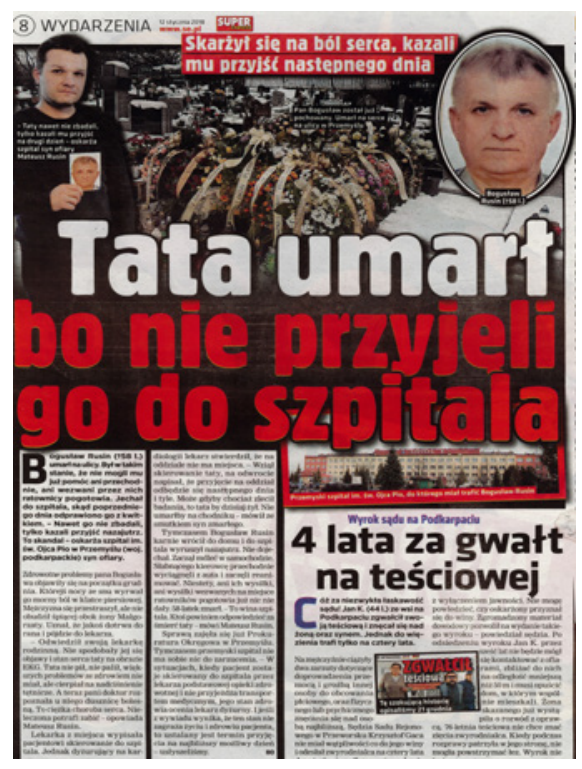

Fot. 1. Przykład „medialnej” perspektywy pacjenta [„Super Express” 12.01.2018, 9: 8]. 


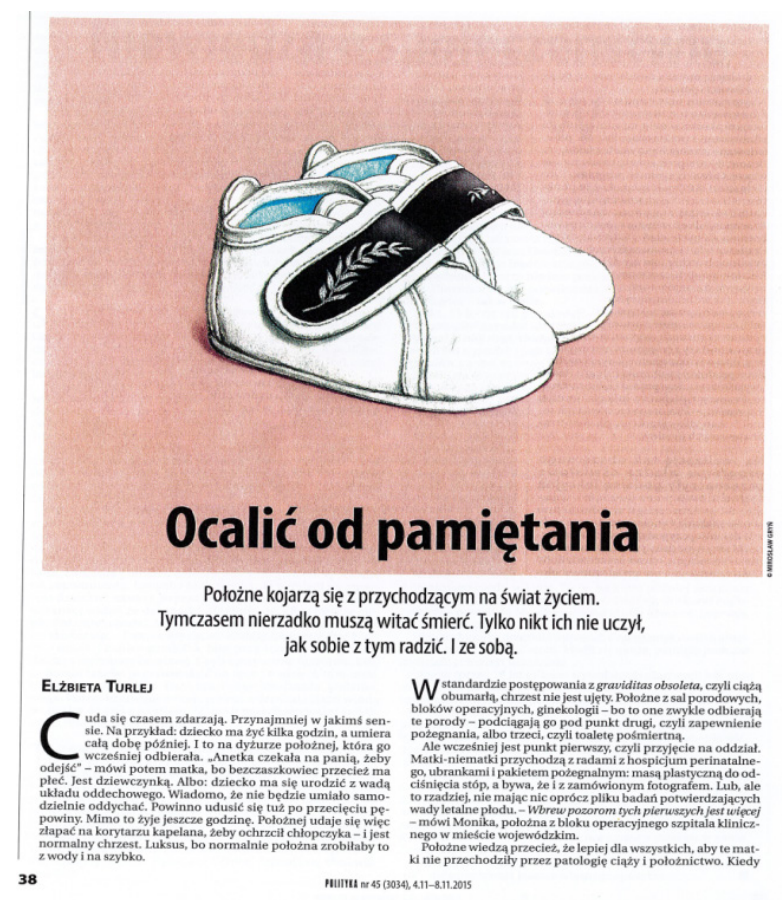

Fot. 2. Przykład „medialnej” perspektywy pracowników jednej z grup zawodowych służby zdrowia, tj. położnych [„,Polityka” 4.11.-8.11.2015, 45: 38-39].

W mediach drukowanych jest też miejsce na specjalne, „medyczne” dodatki, w całości skierowane do pacjentów. Tematyka w nich jest bardzo różnorodna od rad i porad, po wywiady z przedstawicielami branży medycznej, jak również różnego rodzaju rankingi usług i przychodni lekarskich.

W zdecydowanej mniejszości we współczesnych mediach pojawiają się materiały pokazujące lekarza i pacjenta - obu interlokutorów - na tej samej płaszczyźnie. Dlatego, mając świadomość, jak skomplikowana bywa próba porozumienia między nimi, warto na przykładzie takiej publicystyki o tematyce medycznej zwracać uwagę i doceniać wysiłki jej autorów. Teksty, których kompozycja jest oparta na próbie poprawienia kontaktów środowisk pacjentów i medyków, prezentują różne metody postępowania. Czasami są to metody tradycyjne, polegające na zaleceniu przez dziennikarza lekarzowi empatycznej i wyczerpującej rozmowy z pacjentem oraz pocieszaniu, które niektórzy uważają za fundament współczesnej medycyny [Walewski 2017: 97]. Czasami są to metody bardziej awangardowe, jak propozycja skorzystania z pomocy tzw. ambasadorów, którymi najczęściej są celebryci, światowego lub krajowego formatu. Zdaniem nie tylko mediów, ale i specjalistów public relations, celebrytom łatwiej jest trafić z komunikatem do społecznej świadomości, dlatego mogą oni pomóc w przekazaniu ważnej informacji medycznej; nie tylko ułatwić komunikację lekarza specjalisty z potencjalnym pacjentem, ale i zdopingować go do działania. 
W ostatnich latach media masowe niejednokrotnie skupiały się na profilaktyce zdrowotnej, a polegało to na kolportowaniu informacji na temat ważnych problemów medycznych. Głównymi postaciami materiałów dziennikarskich byli właśnie celebryci. To oni niejako komunikowali się z potencjalnymi pacjentami. Jedną z najbardziej rozpoznawanych ambasadorek stała się Angelina Jolie, która opowiadając o usunięciu jajników i wcześniejszej obustronnej mastektomii, pokazywała kobietom, jak mogą ustrzec się raka. Jolie światowe media nazwały ambasadorką badań profilaktycznych. W Polsce między innymi Barbara Kurdej--Szatan i Piotr Gruszka wspierali chorych z dziecięcym porażeniem mózgowym [Walewski 2015]; Andrzej Zieliński zachęcał do robienia kolonoskopii; Jerzy Stuhr apelował o uśmierzanie bólu w chorobach nowotworowych i pomoc psychoonkologiczną; Natalia Kukulska informowała o potrzebie badań znamion na skórze; Ada Fijał namawiała ciężarne do poddawania się testom na HIV; Jacek Kawalec zachęcał do zjadania drugich śniadań i szczepień przeciwko kleszczowemu zapaleniu mózgu; a Natalia Siwiec była ambasadorką kampanii „Płodny Polak" i namawiała mężczyzn do badania płodności.

Za inny, także awangardowy, medialny sposób komunikacji lekarz-pacjent uważa się memy internetowe, które podobnie jak ambasadorzy-celebryci mają za zadanie przystępne tłumaczenie skomplikowanych zagadnień medycznych oraz oswajanie rzeczywistości szpitalnej potencjalnym pacjentom. Ironia, drwina, groteska, surrealizm mają odstresowywać (abstrahując od pojawiających się w memach „medycznych” treści przepełnionych agresją i wulgaryzmami).

\section{KONKLUZJE}

W artykule starano się opisać i zdiagnozować stan oraz sposób komunikacji lekarza z pacjentem. By tego dokonać, wyróżniono trzy aspekty związane z tym bardzo szerokim problemem. Po pierwsze, zaprezentowano sytuacje, które na co dzień występują w kontaktach pomiędzy tymi dwoma grupami społecznymi (czasami może dojść do zaburzenia podziałów, kiedy pracownik służby zdrowia również staje się pacjentem), ich specyfikę, niezręczności, ale też coraz większą świadomość potrzeby pogłębiania wiedzy w tej materii. Po drugie, starając się zrozumieć sposób i jakość komunikacji w medycynie, spojrzano na problem z perspektywy językoznawczej, gdzie niezastąpione wydają się być analizy Walerego Pisarka. Po trzecie, zaprezentowano wybrane publikacje skoncentrowane na poruszanym problemie, jak również zwrócono uwagę na różnorodność prezentowanych przez ich autorów stanowisk. Materiały dziennikarskie dotyczące komunikowania lekarzy i pacjentów oferują szerokie pola analiz. Po ich lekturze pojawiają się liczne pytania, m.in.: Czy faktycznie te dwa środowiska funkcjonują w tak odległych od siebie sferach? Czy może to dziennikarze preferują pewien rodzaj tematów, które determinują kontakty lekarza i pacjenta? 
Badania nad publicystyką medialną pochylającą się nad komunikacją w relacji lekarz-pacjent wydają się być obiecujące. Mogą dać odpowiedź, czy popularność tematu wynika z powszechności problematyki (tj. każdy jest potencjalnym pacjentem), czy bardziej z tradycyjnie widzianej niedoskonałości aktu komunikacji pomiędzy lekarzami i ich pacjentami? Czy może z chęci kolportowania materiałów sensacyjnych, voyeurystycznych, wykorzystujących ludzką słabość, eksplorujących momenty graniczne? A może ze wszystkich przyczyn jednocześnie? Konkludując, analiza komunikowania w medycynie, w perspektywie materiałów pojawiających się we współczesnych polskich mediach, okazuje się być atrakcyjnym i niewyczerpanym polem badawczym, które warto poznawać.

\section{Title: Communication on Health and Medicine - Reality and Media Communications}

Summary: The article discusses problems arising in communication between a health care professional (doctor, nurse, medical rescuer, dentist, physiotherapist, pharmacist) and the patient. The author indicates the asymmetry of these relations, shows the difference between the two ways of communication - authoritarian and partner, and tries to study and describe the obstacles that hinder the patient-doctor relationship. Based on individual examples, she tries to show how contemporary media, especially the press, undertake and implement this topic.

Keywords: communication on health and medicine, media coverage on health and medicine, partner communication, authoritarian communication, verbal and non-verbal communication, communication barriers

\section{BIBLIOGRAFIA}

1. Barański J., Steciwko A., 2013, Rola gabinetu lekarskiego w budowaniu relacji lekarz-pacjent, [w:] Relacja lekarz-pacjent, red. J. Barański, A. Steciwko, Wyd. Elsevier Urban \& Partner, Wrocław.

2. Barański J., Waszyński E., Steciwko A., 2017, Komunikowanie się lekarza z pacjentem, Wyd. Astrum, Wrocław.

3. Boczek K., Porozmawiaj z pacjentem, www.medexpress.pl/lekarz/porozmawiaj-z-pacjentem/7992/.

4. Christy N., 1979, Medspeak, „The New England Journal of Medicine”, no 9, p. 508.

5. Cieśla J., 2018, Kto pójdzie pod parawan?, „Polityka”, nr 25, s. 30-32.

6. Emanuel E.J., Emanuel L.L., 1992, For models of the physician - patient relationship, "The Journal of the American Medical Association" April 22/29, vol. 267, no 16, p. 2221-2226. DOI: https://doi.org/10.1001/jama.1992.03490110048022.

7. Goban-Klas T., 1999, Media i komunikowanie masowe. Teorie i analizy prasy, radia, telewizji i Internetu, Wyd. PWN, Warszawa-Kraków.

8. Hartman J., 2012, Wtadza i medycyna, „Polityka”, nr 5, s. 36.

9. Hebanowski M., Kliszcz J., Trzeciak B., 1995, Poradnik komunikowania się lekarza z pacjentem, Wyd. Lekarskie PZWL, Warszawa. 
10. Hołdys A., 2003, Poczucie humoru, czyli dlaczego warto się śmiać. Chichot neuronów, „Gazeta Wyborcza”, dodatek „Nauka”.

11. Jarosz M.J., Kawczyńska-Butrym Z., Włoszczak-Szubzda A., 2012, Modele komunikacyjne relacji lekarz-pacjent-rodzina, „Medycyna Ogólna i Nauki o Zdrowiu”, t. 18, nr 3, s. 212-218.

12. Kowalska A.J., Włoszczak-Szubzda A., Jarosz M.J., 2011, Problemy komunikowania się pracowników medycznych z pacjentami głuchymi i głuchoniemymi, „Medycyna Ogólna i Nauki o Zdrowiu", t. 17, nr 2, s. 96-99.

13. Lux Med.: komunikacja „Lekarz - Pacjent” oceniana po każdej wizycie, www.medycynaprywatna.pl/lux-med-komunikacja-lekarze-pacjenci [dostęp: 2.10.2013].

14. Motyka H., 2013, Komunikacja interpersonalna w opiece medycznej, „Medycyna Rodzinna” nr 4, s. 124-128.

15. Nowina-Konopka M., 2016, Komunikacja lekarz-pacjent. Teoria i praktyka, Wyd. Instytut Dziennikarstwa, Mediów i Komunikacji Społecznej UJ, Kraków.

16. Ostrowska A., 2001, Elementy kultury zdrowotnej społeczeństwa polskiego. Relacja pacjentlekarz: nowa jakość?, „Promocja Zdrowia. Nauki Społeczne i Medycyna”, nr 21, s. 109-122.

17. Ostrowska A., 2011, Paternalizm i partnerstwo. Społeczny kontekst relacji pacjent-lekarz, [w:] Etyczne aspekty decyzji medycznych, red. J. Hartman, M. Waligóra, Wyd. Lex a Wolters Kluwer business, Warszawa.

18. Pisarek W., 2008, Wstęp do nauki o komunikowaniu, Wyd. Akademickie i Profesjonalne, Warszawa.

19. Rakowska A., 2003, Język komunikacja niepetnosprawność, Wyd. Naukowe Akademii Pedagogicznej w Krakowie, Kraków.

20. Salmon P., 2002, Psychologia w medycynie wspomaga wspótpracę z pacjentem i proces leczenia, Gdańskie Wydawnictwa Psychologiczne, Gdańsk.

21. Stangierska I., Horst-Sikorska W., 2007, Ogólne zasady komunikacji między pacjentem i lekarzem, „Forum Medycyny Rodzinnej”, nr 1, s. 58-68.

22. Szewczyk K., 2009, O bezsensie i potrzebie konstruowania modeli relacji lekarz pacjent, „Krytyka Lekarska", nr 2-3, s. 17-38.

23. Walewski P., 2015, Twarze chorób, „Polityka”, nr 19, s. 94-96.

24. Walewski P., 2017, Stowo też leczy, „Polityka”, nr 51/52, s. 96-98.

25. Woźnicka A., O medycynie z uśmiechem, „Lekarski Poradnik Językowy”, www.lpj.pl.

26. Zembala A., 2015, Modele komunikacyjne w relacjach lekarz-pacjent, „Zeszyty Naukowe Towarzystwa Doktorantów UJ Nauki Ścisłe”, nr 11, s. 35-50. 